Article

\title{
Evaluation of Electrochemical Methods for Poultry Slaughterhouse Wastewater Treatment
}

\author{
Kulyash Meiramkulova ${ }^{1}{ }^{(D}$, Zhanar Jakupova ${ }^{2}$, Duman Orynbekov ${ }^{3}$, Erbolat Tashenov ${ }^{2}{ }^{\mathbb{D}}$, \\ Aliya Kydyrbekova ${ }^{1}$, Timoth Mkilima ${ }^{4}$ (D) and Vassilis J. Inglezakis ${ }^{5,6, *(\mathbb{D})}$
}

1 Department of Environmental Engineering and Management, L.N. Gumilyov Eurasian National University, Satpayev Street 2, Nur-Sultan 010000, Kazakhstan; kuleke@gmail.com (K.M.); aliyafromkz@gmail.com (A.K.)

2 Department of Chemistry, L.N. Gumilyov Eurasian National University, Satpayev Street 2,

Nur-Sultan 010000, Kazakhstan; zhanerke@mail.ru (Z.J.); tashenovyerbolat@gmail.com (E.T.)

3 Department of Sciences and Technology, L.N. Gumilyov Eurasian National University, Satpayev Street 2, Nur-Sultan 010000, Kazakhstan; duman_r@mail.ru

4 Department of Civil Engineering, L.N. Gumilyov Eurasian National University, Satpayev Street 2, Nur-Sultan 010000, Kazakhstan; tmkilima@gmail.com

5 Department of Chemical \& Materials Engineering, Environmental Science \& Technology Group (ESTg), School of Engineering, Nazarbayev University, Nur-Sultan 010000, Kazakhstan

6 Environment \& Resource Efficiency Cluster (EREC), Nazarbayev University, Nur-Sultan 010000, Kazakhstan

* Correspondence: vasileios.inglezakis@nu.edu.kz or v_inglezakis@yahoo.com

Received: 8 May 2020; Accepted: 19 June 2020; Published: 23 June 2020

check for updates

\begin{abstract}
Understanding the efficiency of different wastewater treatment technologies tested under real conditions is essential for successful decision making by engineers and managers. In this study, real poultry slaughterhouse wastewater coming from defeathering, cooling, and evisceration processes was treated using a lab-scale electrochemical process by use of iron-iron (Fe-Fe), iron-graphite (Fe-Gr) and aluminum-graphite (Al-Gr) electrode combinations. A water quality index (WQI) was developed and used as a tool for evaluating and classifying the effectiveness of different electrode combinations. The Al-Gr electrode combination showed an impressive performance achieving an "excellent" status for all of the three studied sources of wastewater with a WQI ranging from 13 to 34. The Fe-Gr electrode combination showed an "excellent" status performance for the wastewater from the cooling process as classified by the WQI and "good water" class for the defeathering and evisceration processes. The lower performance, which was highly affected by the increase in turbidity, was observed for the Fe-Fe electrode combination with a "poor water" status for the wastewater coming from defeathering and cooling processes and "good water" status for evisceration process.
\end{abstract}

Keywords: electrochemical treatment; electrodes; poultry slaughterhouse wastewater; water quality index

\section{Introduction}

Poultry slaughterhouse wastewater originates from meat production processes containing high concentrations of organic substances. The produced wastewater is highly polluted and requires treatment before discharging to the environment [1]. The quantity of wastewater discharged from a poultry plant operations is estimated to be from 20 to $40 \mathrm{~L}$ per bird, with $25 \mathrm{~L}$ being a typical value [2]. Excessive usage of water in a poultry farm leads to the release of huge amounts of wastewater characterized by high concentrations of pollutants $[3,4]$. The wastewater generated from a poultry slaughterhouse contains high organic content (chemical oxygen demand (COD), biochemical oxygen demand (BOD)) due to protein and fats, fibers, pathogens, veterinary pharmaceuticals, total nitrogen (TN), total phosphorus (TP), and total suspended solids (TSS) [5]. Depending on the desired degree of 
treatment, poultry wastewater is treated by using physical, chemical, and biological treatment systems. Each treatment technology possesses advantages and disadvantages. The advantage of biological treatment systems (anaerobic and aerobic) is the great adaptability of microorganisms to a wide variety of wastewater composition. However, the biological treatment systems are slow treatment processes requiring a large physical area and generating large amounts of sludge [6]. Electrochemical processes offer an alternative as they are robust, require little space, are easy to operate, and they are flexible under fluctuating wastewater composition [7]. However, the variability of electrode materials and design, as well as wastewater characteristics, makes it challenging to predict the behavior of electrochemical wastewater treatment systems [8].

In recent years, there has been a growing interest in electrochemical (EC) technologies for wastewater treatment $[9,10]$. An electrochemical system consists of at least two electrodes, an anode and a cathode, and an intermediate space filled with electrolyte [11,12]. Either a voltage source (electrolysis cell) or an electrical load (galvanic element) is essential for the electrical circuit, which is closed through electrical wires. Furthermore, in most cases, either a membrane or diaphragm (acting as a separator) is used to separate the reactor into an anode and cathode compartment [7]. The electrodes can be arranged in a monopolar or bipolar mode. Several materials including aluminum, graphite, and iron in a plate or packed form of scraps, such as steel turnings and millings, have been used [13]. When the system is connected to a power source, the oxidation process occurs in the anode, making it electrochemically corroded, while passivation occurs in the cathode where, during the process, amorphous $\mathrm{M}(\mathrm{OH})_{3}$, also known as sweep flocs, are formed. The formed amorphous $\mathrm{M}(\mathrm{OH})_{3}$ is useful for the removal of colloidal particles through a rapid adsorption of soluble organic compounds [14]. In addition, through polymerization, the formed flocs can be removed by sedimentation and floatation [15]. Despite the general applicability of the electrochemical technologies for treating wastewater of different kinds, they have also been increasingly used for the treatment of poultry wastewater [16-18] under different electrode combinations, such as using aluminum electrodes [19] as well as iron electrodes [20]. Moreover, the performance of electrodes in a wastewater treatment system can be highly affected by the choice of electrode materials [21], combination [22], as well as the characteristics of the wastewater to be treated. The characteristics of a poultry slaughterhouse wastewater are source-dependent even within the same facility. Understanding the response of wastewater when subjected to a treatment system is a key aspect of designing efficient processes. Although various studies [23-25] have shown the general performance of the electrochemical technologies for the treatment of poultry slaughterhouse wastewater, the response of a poultry slaughterhouse wastewater treatment system when subjected to different combinations of electrode materials has not been comprehensively studied. Therefore, a comparison of different electrode combinations for a wastewater treatment system is of great importance before adopting a certain combination. The present study provides a comprehensive comparative analysis in terms of performance for three types of electrode combinations for poultry slaughterhouse wastewater with the help of a water quality index (WQI).

Understanding all alternative wastewater treatment scenarios and the achieved water quality requires technical knowledge, which makes the need for simple and easy ways to present the results attractive and even necessary. The typical manner of presenting water quality reports may be too technical, detailed, and hard to understand, especially for readers who are not from the water quality field. Moreover, this kind of analysis produces some doubtful results; for example, presenting lab analysis results with many parameters and different concentrations with different units cannot be easily understandable by non-experts [26]. The use of the WQI is one of the handy ways to present information related to water quality with an easy-to-understand approach $[27,28]$. The WQI approach for water quality analysis has been widely used in various studies [29-31]. A WQI provides a summary of a technical and large amount of data from water quality analyses by replacing them with simplified terms such as extremely bad, bad, good, and excellent which are easier for non-experts to understand [32]. In 1965, Horton defined the WQI with a status classification from poor to the ideal, where the range 
was from 0 to 100 [33]. The definition was based on eight indicators or parameters of water quality, which were given a weight following their influence on the quality of water. The National Sanitation Foundation (NSF-WQI) of the United States and the Canadian Council of Ministers of the Environment (CCME-WQI) of Canada are members of the organizations that have been working on water quality indices for many years. There have been many research studies since then that have utilized and developed the idea further [34-36]. Despite many approaches and methodologies for water quality evaluation, there are still some challenges in the field, such as the selection of the appropriate water quality parameters for a particular requirement [37].

In this study, wastewater samples collected from the Izhevski poultry slaughterhouse industry in Izhevskoye village, Kazakhstan, were used. Three wastewater samples coming from different poultry slaughterhouse production processes were used, namely defeathering, evisceration, and cooling. The samples were transported to the Water and Environmental Management laboratory at the L.N. Gumilyov Eurasian National University for analysis and then treated in a lab-scale electrochemical process by using three different electrode combinations: iron to iron ( $\mathrm{Fe}-\mathrm{Fe})$, iron to graphite (Fe- $\mathrm{Gr}$ ), and aluminum to graphite (Al-Gr). This study aimed to utilize the potential of the WQI as a tool for assessing the performance of different electrode combinations for purifying wastewater from a poultry slaughterhouse. Based on the developed WQIs, the quality of the treated water obtained from each of the three electrode combinations was then classified from the "excellent" status to the "unsuitable for drinking" status, with drinking water as a reference. The selection of drinking-water quality standards as references was based on the fact that the studied treatment methods were investigated for their potential to produce high-quality water for the cooling section of the slaughterhouse.

\section{Materials and Methods}

\subsection{Industrial Case Study Description}

The wastewater samples were collected from the Izhevski poultry farm, from the slaughterhouse section located in Izhevskoye village in Kazakhstan, $70 \mathrm{~km}$ from the capital city, Nur-Sultan. Several samples were taken from the poultry farm over a period of two years. Samples were collected from the main sources of wastewater generation in the slaughterhouse, namely defeathering, evisceration, and cooling. Most of the lab experiments were done on the same day of sample collection. Table 1 shows the wastewater characteristics and the guidelines according to drinking water standards in Kazakhstan.

Table 1. Raw wastewater characterization. TSS: total suspended solids; COD: chemical oxygen demand.

\begin{tabular}{|c|c|c|c|c|c|}
\hline Parameter & Defeathering & Evisceration & Cooling & Units & Guidelines \\
\hline Turbidity & 196 & 238 & 172 & FAU $^{1}$ & Clear \\
\hline TSS & 337 & 374 & 266 & $\mathrm{mg} / \mathrm{dm}^{3}$ & Clear \\
\hline Free chlorine & 0 & 0.24 & 0 & $\mathrm{mg} / \mathrm{dm}^{3}$ & $0.5-2.0$ \\
\hline Nitrates & 25.8 & 84.4 & 49.3 & $\mathrm{mg} / \mathrm{dm}^{3}$ & 45 \\
\hline Phosphates and total phosphorous & 4.84 & 4.99 & 5.23 & $\mathrm{mg} / \mathrm{dm}^{3}$ & 2 \\
\hline Ammonium & 2.07 & 0.43 & 1.59 & $\mathrm{mg} / \mathrm{dm}^{3}$ & 3.5 \\
\hline COD & 2009 & 1927 & 1646 & $\mathrm{mg} / \mathrm{dm}^{3}$ & 1000 \\
\hline Total coliform & 1365 & 1122 & 936 & $\mathrm{CFU}^{1} / 100 \mathrm{~mL}$ & None \\
\hline
\end{tabular}

${ }^{1} \mathrm{FAU}=$ Formazin Attenuation Units, $\mathrm{CFU}=$ Colony-forming unit.

\subsection{Experimental Setup and Procedures}

A reactor of $2145 \mathrm{~cm}^{3}(15 \times 13 \times 11 \mathrm{~cm})$ made of polypropylene was used for the electrochemical process. A combination of electrodes was placed and then supplied with direct current from a power supply (Xinhua electrical weld company) in the range of $0-50 \mathrm{~V}$ for voltage and 0-10 A for 
current density. The following electrode combinations were studied: iron-iron (Fe-Fe), iron-graphite (Fe-Gr), and aluminum-graphite (Al-Gr). Fe-Fe electrode dimensions were $13 \times 13 \times 0.05 \mathrm{~cm}$. Fe-Gr electrode, with Gr as the anode and Fe as the cathode, had dimensions of $10.8 \times 11.8 \times 0.7 \mathrm{~cm}$ and $13 \times 12 \times 0.05 \mathrm{~cm}$, respectively. The Al-Gr electrode, with $\mathrm{Al}$ as the cathode and $\mathrm{Gr}$ as the anode, had dimensions of $10.8 \times 11.8 \times 0.2 \mathrm{~cm}$ and $10.8 \times 11.8 \times 0.7 \mathrm{~cm}$, respectively. For all configurations, the electrodes were placed in parallel and had the same fixed distance of $2 \mathrm{~cm}$ between them. Figure 1 presents the general setup of the experiment.

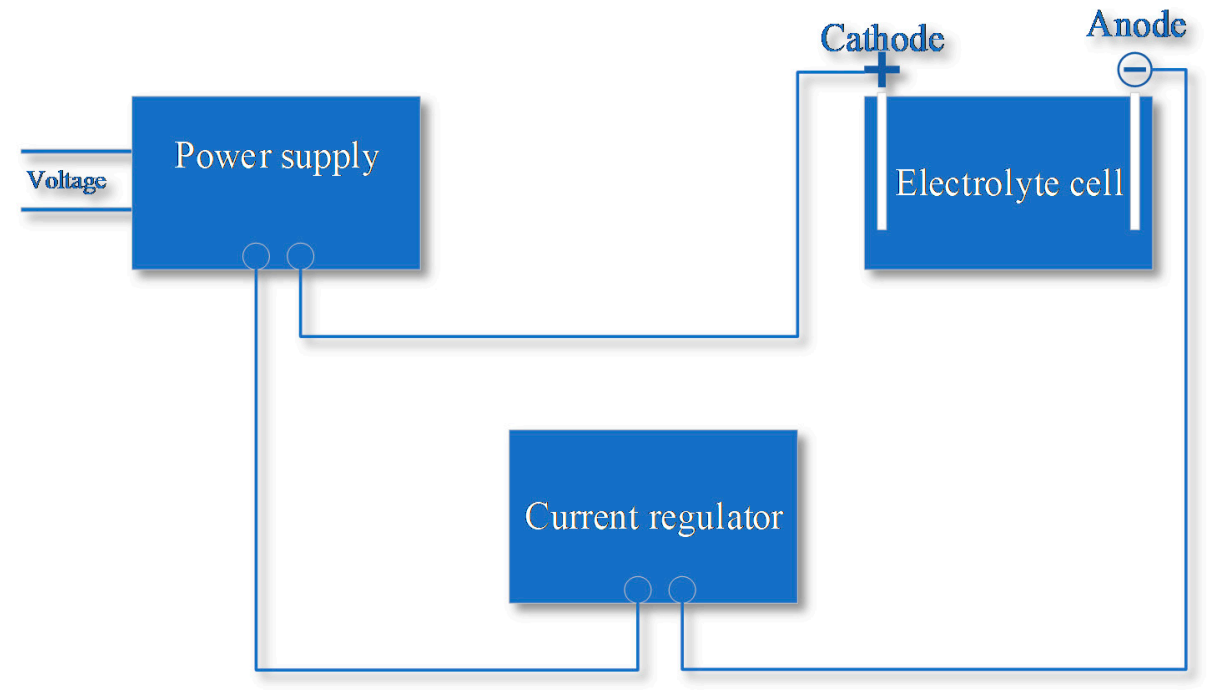

Figure 1. Electrolysis process setup.

\subsection{Analytical Methods}

The collected wastewater samples were transported to the lab using $5 \mathrm{~L}$ plastic bottles, which were well rinsed with deionized water before use. The chemical parameters were analyzed using the combination of Spectrophotometer (Hach DR3900, HACH/LANGE, Germany) and Colorimeter (Hach DR900) with standard reagents as well as the test kits. The Standard Operating Procedure for GLNPO Turbidity (The U.S. Environmental Protection Agency Great Lakes National Program Office) was used for the analysis of turbidity [38], and the American Public Health Association 4500-Nor was used for the analysis of total phosphorous, while lab $\mathrm{pH}$-meter (Hach Co.) was used for $\mathrm{pH}$ measurements. Color measurement was achieved through absorbance by an Ultraviolet-Visible (UV-V) Spectrophotometer (PE-5400UV). The TSS in the samples was determined using the Hach TSS portable hand-held turbidity meter. COD was measured by a closed reflux reactor and direct reading spectrophotometer (DR3900 Hach). Free chlorine, total chlorine, nitrites, nitrates, phosphates, and ammonia were determined by a Hach DR3900 spectrophotometer using standard reagents and test units. The membrane filtration method was used for the microbiological analysis [39], where the water samples were passed through a membrane filter with a pore size of $0.45 \mu \mathrm{m}$ and incubated on an agar plate at $37^{\circ} \mathrm{C}$ for $48 \mathrm{~h}$. In general, the analyses of the samples were accomplished following the recommendations in the APHA Standard Methods for the Examination of Water and Wastewater [40].

\subsection{Calculation of WQI}

The weight arithmetic WQI method was used to classify the quality of the treated water with respect to the degree of purity. Nine parameters were selected for the development of WQI, namely nitrites, total coliforms, $\mathrm{pH}, \mathrm{COD}$, nitrates, phosphates, ammonia nitrogen, turbidity, and TSS. The first step was to assign different weight $\left(w_{i}\right)$ to each of the case parameters on a scale of 0 to 1 (Table 2), where 0 is for the lowest effect on water quality while 1 is for the highest effect. The weighting process was based on the perceived effects of the water quality parameters on the intended use. 
The parameters weighting was done following the United States National Sanitation Foundation Water Quality Index (NSFWQI) guidelines [41]. However, there were slight adjustments to the weighting approach developed by NSFWQI, but the general idea remained the same.

Table 2. Weights $\left(w_{i}\right)$ of the parameters used in the study.

\begin{tabular}{cc}
\hline Parameter & $w_{\boldsymbol{i}}$ \\
\hline Nitrate & 0.12 \\
Total coliforms & 0.17 \\
$\mathrm{pH}$ & 0.11 \\
COD & 0.13 \\
Nitrites & 0.12 \\
Phosphates & 0.1 \\
Ammonia nitrogen & 0.1 \\
Turbidity & 0.07 \\
TSS & 0.08 \\
\hline Total & 1.00 \\
\hline
\end{tabular}

Then, the relative weight $(\mathrm{Wi})$ was calculated from the following equation:

$$
W i=\frac{w_{i}}{\sum_{i=1}^{n} w_{i}}
$$

where $W i$ (with capital $W$ ) refers to relative weight, $w_{i}$ is the weight of individual parameters, and $\mathrm{n}$ accounts for the number of parameters being studied. Then, the calculation of the relative weight (Wi) followed by assigning the quality rating $(q i)$ to each parameter, which was computed by dividing its concentration with its corresponding minimum recommended concentration value provided by the WHO (2008). The obtained value was then multiplied by 100, as shown in Equation (2):

$$
q_{i}=\frac{C_{i}-C_{i d}}{S_{i}-C_{i d}} \times 100
$$

where $q_{i}$ is the quality rating, $C_{i}$ is the concentration of individual parameters, and $C_{i d}$ is the ideal value of the ith parameter in pure water. All ideal values $\left(C_{i d}\right)$ were taken as zero for drinking water, except for $\mathrm{pH}$ [42]. For $\mathrm{pH}$, the ideal value is 7 (for natural/pure water) and a permissible value is 8.5 (for polluted water), and $S_{i}$ is the recommended water standard (a case of drinking water) for each parameter, as recommended by the WHO (2008).

To calculate the WQI, the $S I_{i}$ value was calculated as illustrated in Equation (3):

$$
S I_{i}=W_{i} \times q_{i}
$$

where $S I_{i}$ is referring to the subindex of an ith parameter and $q_{i}$ accounts for the quality rating based on the concentration of the ith parameter.

Finally, the WQI was calculated by summing up all the subindices of each of the studied parameters as follows:

$$
W Q I=\sum_{i=1}^{n} S I_{i}
$$

The characterization of the calculated $W Q I$ was based on the status value categories $[43,44]$, as shown in Table 3. 
Table 3. Water quality index (WQI) with the corresponding water quality status.

\begin{tabular}{cc}
\hline WQI Value & Water Quality Status \\
\hline$<50$ & Excellent water \\
$50-100$ & Good water \\
$100-200$ & Poor water \\
$200-300$ & Very poor water \\
$>300$ & Water unsuitable for drinking/irrigation \\
\hline
\end{tabular}

\subsection{Cost Analysis}

The estimation of the operational costs for the three studied electrode combinations was based on the current unit prices in Kazakhstan. The electricity price was $0.05 \mathrm{US} \$ / \mathrm{kWh}$, the Fe electrode material price was $0.93 \mathrm{US} \$ / \mathrm{kg}$, the Al electrode average price was $32.25 \mathrm{US} \$ / \mathrm{kg}$, and that of Gr electrode was 16.5 US $\$ / \mathrm{kg}$. It should be also noted that $\mathrm{Gr}$ is a stable inert electrode, and the electrodes are not consumed during the electrochemical process leading to a positive impact on the total operating cost as no replacement is required.

$$
\text { Operating cost }=X \times \text { Energy }_{\text {consumpion }}+Y \times \text { Electrode }_{\text {consumption }}
$$

Equation (6) shows the estimation of energy consumption cost:

$$
\text { Energy } y_{\text {consumption }}=\frac{(V \times I \times t)}{v}
$$

where $V$ is voltage, $I$ is current (Ampere), $t$ is EC time (seconds), and $v$ is the volume of the treated wastewater $\left(\mathrm{m}^{3}\right)$.

Moreover, Faraday's law of electrolysis was used for the estimation of the electrode material consumption as illustrated in Equation (7):

$$
\begin{gathered}
\frac{\text { Faraday }}{m^{3}}=\frac{I \times t}{F \times v} \\
\text { Electrode consumption }=\frac{I \times \times \times M_{w}}{z \times F \times v}
\end{gathered}
$$

where $M_{w}$ is the molar mass of electrode element $(26.98 \mathrm{~g} / \mathrm{mol}), F$ is Faraday's constant $(96,485 \mathrm{C} / \mathrm{mol})$, and $z$ is the number of electron transfer.

\section{Results and Discussion}

\subsection{Physicochemical Parameters}

The analysis of physicochemical parameters was accomplished as illustrated in Tables 4-6. The Fe-Fe electrode combination presented the lowest effluent quality from the defeathering section, with the highest effluent quality observed from the Al-Gr electrode combination from the cooling section.

An interesting phenomenon was observed for the color, turbidity, COD, and TSS under the Fe-Fe electrode combination, where their concentrations increased after 20 minutes of the electrolysis process with wastewater from the defeathering source. During the electrochemical process, direct current was applied, and electrode plates were then dissolved into solution. The scarification of the electrode plates leads to an increased metal concentration in the solution which may in turn precipitate as oxide precipitates [45]. The same phenomenon is described by [46], where the increase in turbidity is due to the iron monomeric species formed during electrocoagulation, the ion $\mathrm{Fe}^{3+}$ facilitates a yellow coloration and also exists in fine particles in the $\mathrm{Fe}(\mathrm{OH})_{3}$ species, which is also characterized by its difficulty to dissolve. The observed increase in turbidity, COD, and TSS under Fe-Fe electrode combination from defeathering wastewater can be linked to the -color formation [47]. According to [48], unlike aluminum anodes, iron tends to dissolve as divalent or trivalent cations, followed by 
hydrolyzation which in turn forms insoluble iron compounds. The phenomenon perceived to be facilitated by the $\mathrm{pH}$ of the solution and the cell potential. Even with the observed rapid increase in COD when the wastewater samples were subjected to the Fe-Fe and Fe-Gr electrode combinations, the electrodes combinations were able to produce some impressive results.

Table 4. Fe-Fe analysis results (number of samples $=12$ ).

\begin{tabular}{cccccccccc}
\hline \multirow{2}{*}{ Indicator } & \multicolumn{3}{c}{ Range (min-max) } & \multicolumn{3}{c}{ AM } & \multicolumn{3}{c}{ STD } \\
\cline { 2 - 10 } & $\mathbf{D}$ & $\mathbf{E}$ & $\mathbf{C}$ & $\mathbf{D}$ & $\mathbf{E}$ & $\mathbf{C}$ & $\mathbf{D}$ & E & C \\
\hline pH & $6.14-6.69$ & $6.04-6.83$ & $6.29-6.85$ & 6.34 & 6.49 & 6.54 & 0.25 & 0.33 & 0.23 \\
Turbidity & $160-436$ & $109-178$ & $61.6-332$ & 319 & 132.7 & 227 & 116 & 32.1 & 118 \\
Color & $2572-7365$ & $1011-3437$ & $1006-7260$ & 5454 & 2176 & 4461 & 2074 & 993 & 2595 \\
TSS & $287-762$ & $146-348$ & $104-592$ & 573 & 228 & 398 & 206 & 86.7 & 212 \\
Free chlorine & $0-0.41$ & $0-3.58$ & $0-0.60$ & 0 & 1.50 & 0 & 1.50 & 1.60 & 1.56 \\
Total chlorine & $0.17-0.61$ & $0-3.72$ & $0-0.68$ & 0.40 & 0.37 & 0 & 0.18 & 2.99 & 1.31 \\
Nitrites & $0-0.12$ & $0-0.37$ & $0.16-0.37$ & 0.00 & 0.12 & 0.27 & 0.16 & 0.19 & 0.09 \\
Nitrates & $18.70-169.6$ & $9.40-175.1$ & $22.8-60.9$ & 78 & 80 & 42.5 & 65.72 & 69.95 & 15.58 \\
Phosphates & $2.60-4.64$ & $1.87-4.13$ & $1.86-3.76$ & 3.49 & 2.86 & 2.93 & 0.85 & 0.94 & 0.79 \\
Ammonium & $1.45-2.28$ & $1.99-2.22$ & $1.92-2.48$ & 2 & 2.18 & 2.15 & 0.39 & 0.13 & 0.17 \\
COD & $1933-4605$ & $618-2113$ & $635-4106$ & 3508 & 1387 & 2673 & 1142 & 611 & 1480 \\
\hline
\end{tabular}

Min = minimum; $\mathrm{AM}=$ arithmetic mean (average); $\mathrm{STD}=$ standard deviation; $\mathrm{D}=$ defeathering; $\mathrm{E}=$ evisceration; $\mathrm{C}=$ cooling; Turbidity in FAU, color in degree, all other parameters in $\mathrm{mg} / \mathrm{dm}^{3}$.

Table 5. Fe-Gr analysis results (number of samples $=12$ ).

\begin{tabular}{cccccccccc}
\hline Indicator & \multicolumn{3}{c}{ Range (min-max) } & \multicolumn{3}{c}{ AM } & \multicolumn{3}{c}{ STD } \\
\hline pH & D & E & C & D & E & C & D & E & C \\
\hline Turbidity & $6.22-6.49$ & $6.08-6.64$ & $5.06-6.14$ & 6.31 & 6.4 & 5.6 & 0.13 & 0.24 & 0.44 \\
Color & $1474-1911$ & $38.3-79.2$ & $9.9-56.2$ & 98 & 65 & 31 & 12 & 18.8 & 19.2 \\
TSS & $158-200$ & $76-144$ & $27-909$ & 1682 & 779 & 604 & 179 & 152 & 259 \\
Free chlorine & $0.02-0.54$ & $0.02-0.52$ & $0.09-0.13$ & 0.21 & 0.26 & 0.10 & 0.22 & 0.20 & 0.02 \\
Total chlorine & $0.03-0.17$ & $0-1.04$ & $0-0.2$ & 0.11 & 0.39 & 0.06 & 0.06 & 0.46 & 0.10 \\
Nitrites & $0.13-0.14$ & $0.01-0.88$ & $0.09-0.31$ & 0.13 & 0.38 & 0.23 & 0.00 & 0.37 & 0.10 \\
Nitrates & $15.8-112$ & $9.4-19.2$ & $0.6-49.3$ & 48.6 & 13.3 & 17.8 & 44.84 & 4.24 & 22.3 \\
Phosphates & $2.98-5.04$ & $4.77-5.27$ & $4.26-5.23$ & 3.86 & 4.96 & 4.77 & 0.87 & 0.22 & 0.40 \\
Ammonium & $2.30-2.98$ & $2.12-2.31$ & $1.59-2.04$ & 2.53 & 2.24 & 1.89 & 0.32 & 0.09 & 0.21 \\
COD & $1076-1309$ & $473-826$ & $179-1646$ & 1205 & 625 & 751 & 96.75 & 148.2 & 640.8 \\
\hline
\end{tabular}

Min = minimum; $\mathrm{AM}=$ arithmetic mean (average); $\mathrm{STD}=$ standard deviation; $\mathrm{D}=$ defeathering; $\mathrm{E}=$ evisceration; $\mathrm{C}=$ cooling; Turbidity in FAU, color in degree, all other parameters in $\mathrm{mg} / \mathrm{dm}^{3}$.

Table 6. Al-Gr analysis results (number of samples =12).

\begin{tabular}{cccccccccc}
\hline \multirow{2}{*}{ Indicator } & \multicolumn{3}{c}{ Range (min-max) } & \multicolumn{3}{c}{ AM } & \multicolumn{3}{c}{ STD } \\
\cline { 2 - 10 } & $\mathbf{D}$ & $\mathbf{E}$ & $\mathbf{C}$ & $\mathbf{D}$ & $\mathbf{E}$ & $\mathbf{C}$ & $\mathbf{D}$ & $\mathbf{E}$ & $\mathbf{C}$ \\
\hline pH & $3.53-6.91$ & $3.33-6.43$ & $4.15-6.49$ & 5.45 & 4.77 & 5.54 & 1.06 & 1.12 & 0.79 \\
Turbidity & $0-171$ & $0-16.1$ & $0-4.44$ & 40.82 & 3.83 & 0 & 63.32 & 8.67 & 3.23 \\
Color & $29-2297$ & $28-406$ & $10-239$ & 698 & 191 & 88 & 821 & 148 & 76 \\
TSS & $3-298$ & $1-37$ & $0-15$ & 79 & 15.2 & 7.2 & 108 & 15.3 & 5.40 \\
Free chlorine & $0-0.74$ & $0.01-0.14$ & $0.01-0.11$ & 0.20 & 0.06 & 0.06 & 0.27 & 0.04 & 0.04 \\
Total chlorine & $0-4.32$ & $0.02-1.90$ & $0.01-3.43$ & 1.36 & 0.83 & 1.22 & 1.46 & 0.73 & 1.50 \\
Nitrites & $0.01-0.17$ & $0.01-0.16$ & $0-0.09$ & 0.06 & 0.04 & 0.02 & 0.05 & 0.05 & 0.03 \\
Nitrates & $0.30-91$ & $0-1.90$ & $0-3.90$ & 20 & 0.45 & 1.03 & 32.2 & 0.99 & 1.33 \\
Phosphates & $0.28-4.78$ & $0.00-2.90$ & $0.08-1.64$ & 2.42 & 0.95 & 0.57 & 1.78 & 1.04 & 0.52 \\
Ammonium & $1.84-2.19$ & $0.38-2.31$ & $0.04-2.31$ & 2.09 & 1.77 & 0.81 & 0.12 & 0.64 & 1.06 \\
COD & $18.9-1974$ & $16.6-283$ & $0-177$ & 544 & 119 & 62.4 & 717 & 109 & 58 \\
\hline
\end{tabular}

Min = minimum; $\mathrm{AM}$ = arithmetic mean (average); $\mathrm{STD}$ = standard deviation; $\mathrm{D}$ = defeathering; $\mathrm{E}$ = evisceration; $\mathrm{C}=$ cooling; Turbidity in FAU, color in degree, all other parameters in $\mathrm{mg} / \mathrm{dm}^{3}$. 
The results revealed that there was a potential relationship between electrode combination, source of wastewater, and performance of a wastewater treatment system, as shown in Tables 4-11. Furthermore, the results showed that the use of electrochemical treatment technology can be an efficient approach for poultry wastewater treatment (see Table 10) as they are also characterized by their high portability where they can be effectively operated under limited space [49].

Table 7. Correlation of $\mathrm{pH}$, turbidity, color, TSS, and COD under Fe-Fe electrolysis.

\begin{tabular}{cccccc}
\hline Parameter & $\mathbf{p H}$ & Turbidity & Color & TSS & COD \\
\hline pH & 1 & & & & \\
Turbidity & 0.187413 & 1 & 1 & & \\
Color & 0.600939 & 0.897756 & 0.933115 & 1 & 1 \\
TSS & 0.273338 & 0.996101 & 0.999338 & 0.919415 & 1 \\
COD & 0.629622 & 0.881135 & 0.9958 & \\
\hline
\end{tabular}

Table 8. Correlation of $\mathrm{pH}$, turbidity, color, TSS, and COD under Fe-Gr electrolysis.

\begin{tabular}{cccccc}
\hline Parameter & $\mathbf{p H}$ & Turbidity & Color & TSS & COD \\
\hline pH & 1 & & & & \\
Turbidity & 0.970269 & 1 & & & \\
Color & 0.90563 & 0.981341 & 1 & 1 & 1 \\
TSS & 0.904194 & 0.980687 & 0.999994 & 0.96482 & 1 \\
COD & 0.76009 & 0.894766 & 0.963928 & & \\
\hline
\end{tabular}

Table 9. Correlation of $\mathrm{pH}$, turbidity, color, TSS, and COD under Al-Gr electrolysis.

\begin{tabular}{cccccc}
\hline & $\mathbf{p H}$ & Turbidity & Color & TSS & COD \\
\hline pH & 1 & & & & \\
Turbidity & 0.492223 & 1 & & & \\
Color & 0.58363 & 0.992765 & 1 & 1 & 1 \\
TSS & 0.506575 & 0.999622 & 0.994854 & 0.999289 & 1 \\
COD & 0.531611 & 0.997955 & 0.997398 & & \\
\hline
\end{tabular}

Table 10. WQI for raw wastewater.

\begin{tabular}{ccc}
\hline Source & WQI & Status \\
\hline Defeathering & $23,321.17$ & Water unsuitable for drinking/irrigation \\
Evisceration & $19,219.10$ & Water unsuitable for drinking/irrigation \\
Cooling & $16,024.00$ & Water unsuitable for drinking/irrigation \\
\hline
\end{tabular}

Table 11. WQI for the three electrode combinations after treatment.

\begin{tabular}{cccc}
\hline Electrode Combination & Source & WQI & Status \\
\hline \multirow{2}{*}{ Fe-Fe } & Defeathering & 119.45 & Poor water \\
& Evisceration & 58.64 & Good water \\
& Cooling & 63.67 & Good water \\
\hline \multirow{2}{*}{$\mathrm{Fe}-\mathrm{Gr}$} & Defeathering & 79.21 & Good water \\
& Evisceration & 66.10 & Good water \\
& Cooling & 43.33 & Excellent \\
\hline \multirow{2}{*}{$\mathrm{Al}-\mathrm{Gr}$} & Defeathering & 33.63 & Excellent \\
& Evisceration & 13.54 & Excellent \\
& Cooling & 16.65 & Excellent \\
\hline
\end{tabular}


Correlation of $\mathrm{pH}$, Turbidity, Color, TSS, and COD

The analyses of the results from the defeathering step subjected to Fe-Fe, Fe-Gr, and Al-Gr electrolysis were used as case studies for assessing the correlation between $\mathrm{pH}$, turbidity, color, TSS, and COD. As seen in Tables 7-9, a correlation between turbidity and color was observed. Color and turbidity are linearly correlated [50] as turbidity measurements may be affected by colored dissolved organic matter [51] and the formed iron monomeric species. The high correlation between turbidity and TSS is linked to the fact that TSS is among the primary factors affecting turbidity as turbidity is a measure of how well light passes through the liquid, while TSS is a quantitative expression of particles in suspension [52]. In general, from all the studied electrodes, it can be observed that changes in $\mathrm{pH}$, turbidity, color, and TSS showed moderate to strong correlation with the changes in COD [53].

\subsection{Microbial Measurements}

Figure 2 illustrates the microorganism population results for the electrochemical process with Fe-Fe electrodes, showing that the microorganism colonies drastically decreased for all samples (defeathering, cooling, and evisceration). For defeathering, the number of colonies reduced by an average of $98 \%$, cooling $100 \%$, and $90 \%$ for evisceration at the end of the experiments. When Fe-Gr electrodes were used, the microbiological results were impressive as the number of colonies decreased by $95 \%, 97 \%$, and $93 \%$ for defeathering, cooling, and evisceration wastewater samples, respectively, at the end of the experiments, as shown in Figure 3. In addition, Figure 4 shows that when the wastewater samples were subjected to the Al-Gr electrode combination, $100 \%$ microorganism colonies removal efficiency was achieved for all samples at the end of the experiments. During the electrochemical disinfection process, microorganisms are killed by a variety of oxidants that are produced during water electrolysis [54]. In the presence of oxygen, electrolysis is capable of generating a variety of oxidants, which includes hydrogen peroxide and ozone, as well as free chlorine and chlorine dioxide, depending on the presence of chloride ions in the solution. The generated oxidants are accountable for most of the lethality of the applied direct current to the microorganisms [55]. Furthermore, another possible mechanism for killing the microorganisms is that the microorganisms could come into contact with the anode surface of the electrodes, be adsorbed by it, and killed electrically [56].

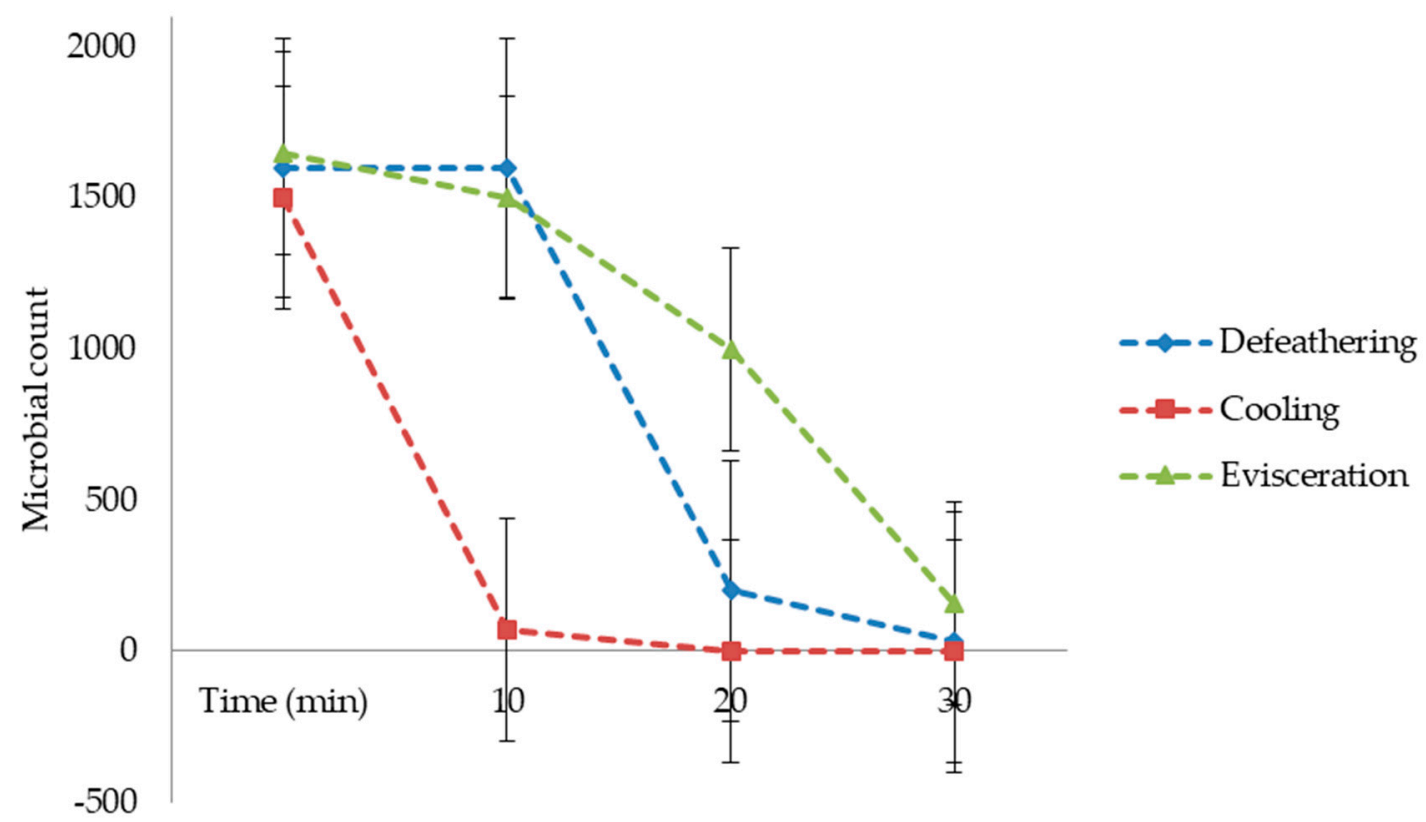

Figure 2. Microbiological results for Fe-Fe electrodes. 


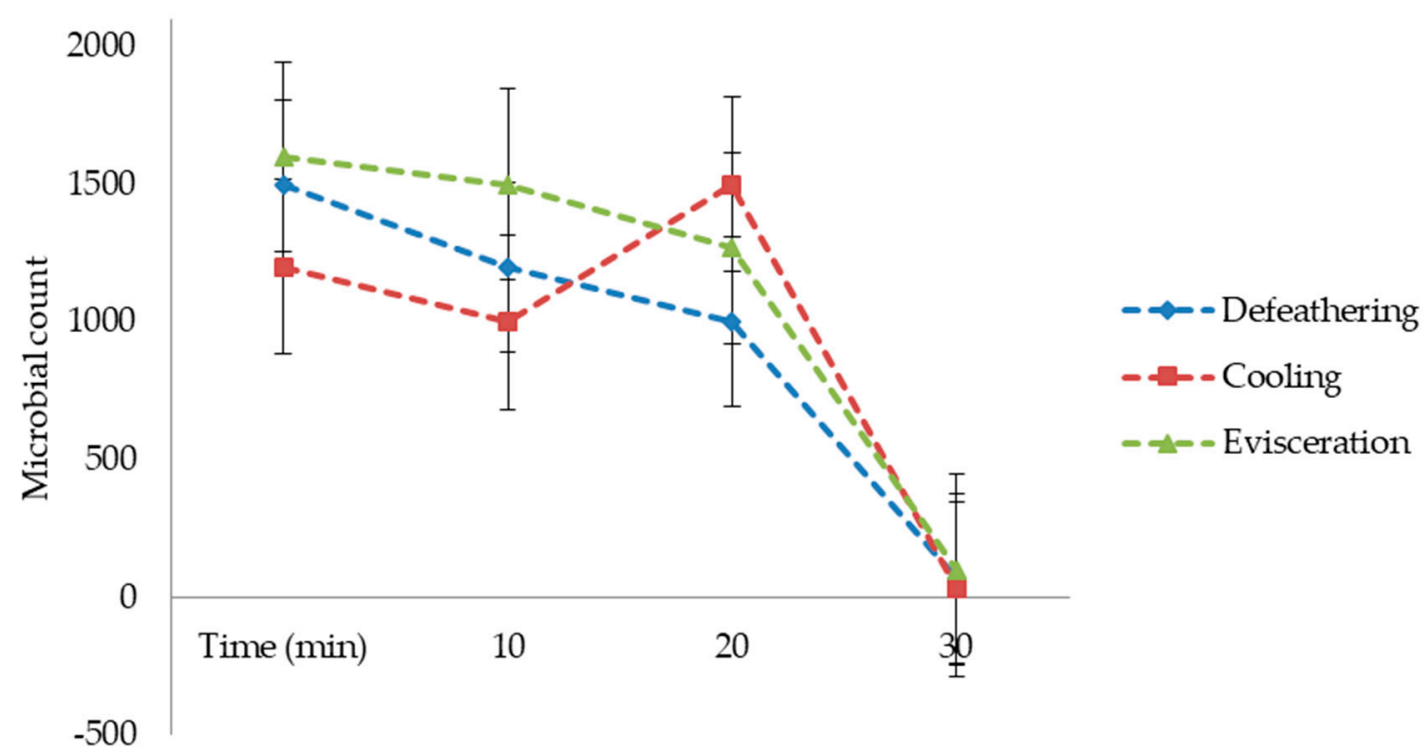

Figure 3. Microbiological results for Fe-Gr electrodes.

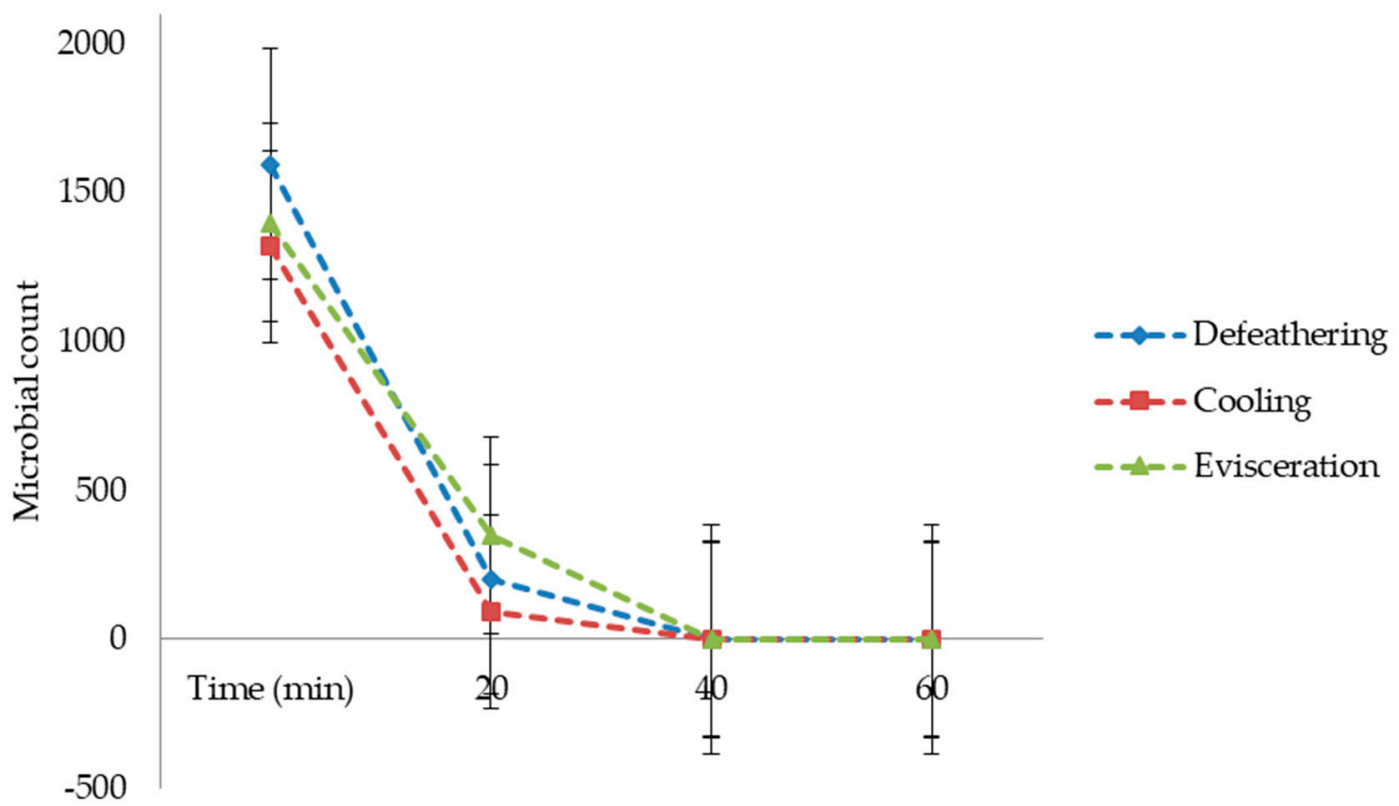

Figure 4. Microbiological results for Al-Gr electrodes.

\section{3. $W Q I$}

Water quality indices from each of the electrode combinations were successfully developed. The classification of the WQI was based on drinking-water quality standards as references. Computed WQIs from raw wastewater were characterized by the "water unsuitable for drinking" status in all of the three studied wastewater sources (Table 10). The highest number of WQI (which also means the lowest quality) from raw wastewater was observed from the defeathering source. The highest water quality was observed from the Al-Gr electrode combination, with the water quality indices ranging from 18.13 to 33.63, which are below 50 and thus categorized as excellent water quality. The wastewater from the defeathering treated under the Fe-Fe electrode combination presented the lowest quality, with indices above 100 and within the range of 100 to 200, and was therefore categorized as poor water quality. The wastewater from the cooling process treated using the Fe-Gr electrode combination presented water of high quality with an excellent status, while those of defeathering and evisceration were close to each other, falling with the class of 50 to 100 and marked with the status of good water. 
Turbidity, TSS, and COD were among the parameters that exhibited the highest influence on the level of treatment performance of the electrode combinations in terms of WQI.

Table 11 shows the water quality indices of the samples collected from defeathering, evisceration, and cooling processes and then purified using $\mathrm{Fe}-\mathrm{Fe}, \mathrm{Fe}-\mathrm{Gr}$, and Al-Gr electrodes with their corresponding statuses. The Fe-Fe electrode combination showed higher treatment performance for wastewater from the evisceration process, as defined from the WQIs compared to the wastewater from the defeathering and cooling processes. From Table 5, it can be observed that the water quality indices derived from the Fe-Gr purified samples from the defeathering, evisceration, and cooling processes of the poultry slaughterhouse industry. The Fe-Gr water quality indices showed an improved level of water quality in comparison to the Fe-Fe electrode combination. The Al-Gr electrode combination presented the highest performance values with an excellent status for all three wastewater sources. The Al-Gr showed high treatment performance from almost all of the tested water quality parameters, including general, the Al-Gr electrode combination showed an impressive performance, achieving $100 \%$ removal efficiency for microorganisms and some of the physical-chemical parameters such as turbidity, followed by the Fe-Gr electrode combination. The degree at which the wastewater from a slaughterhouse will be contaminated depends on many parameters, such as the type of operations [57].

In general, from the WQIs, all three electrodes combination showed high performance on wastewater from the evisceration process (see Figure 3 below), followed by the cooling process. The high pollution strength from the defeathering process can be one of the influencing factors leading to lower treatment performance compared to the wastewater from the other sources [58]. From Figure 5, it can be observed that the highest performance in terms of WQI was from the combination of the wastewater from the evisceration process and the Al-Gr electrode combination. Moreover, the lowest performance was observed from the combination of the wastewater from the defeathering process and the Fe-Fe electrode combination. The Fe-Gr electrode combination presented moderate performance with the wastewater from the defeathering and evisceration and high performance for the wastewater from the cooling process of the poultry slaughterhouse industry.

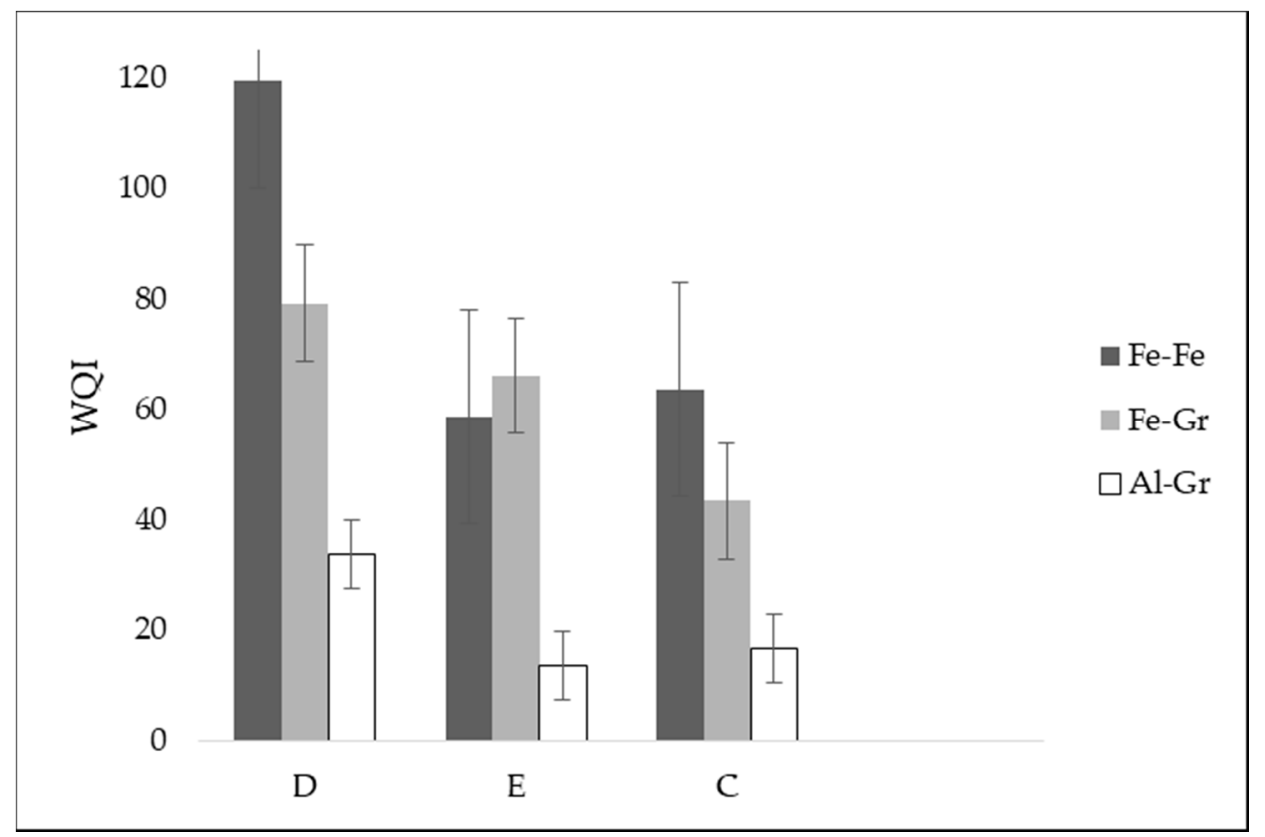

Figure 5. General WQIs from all of the wastewater sources and electrode combinations. D = defeathering; $\mathrm{E}=$ evisceration; $\mathrm{C}=$ cooling.

To determine the general performance of each electrode combination for the poultry slaughterhouse wastewater purification, the cumulative approach of the individual WQIs was applied (Table 12). 
The highest quality value of 63.83 was observed from the Al-Gr electrode combination, which showed high efficiency in the COD, TSS, and turbidity removal from all of the three sources of wastewater.

Table 12. Cumulative WQIs.

\begin{tabular}{cccc}
\hline \multirow{2}{*}{ Source } & \multicolumn{3}{c}{ Electrode Indices } \\
\cline { 2 - 4 } & Fe-Fe & Fe-Gr & Al-Gr \\
\hline Defeathering & 119.45 & 79.21 & 33.63 \\
Defeathering + Evisceration & 178.09 & 145.31 & 47.18 \\
Defeathering + Evisceration + Cooling & 241.76 & 188.64 & 63.83 \\
\hline
\end{tabular}

In general, after the purification process, the wastewater samples collected from the evisceration process showed the best water quality results (see Figure 5), followed by the water from the cooling process. This result shows that the level of pollution loading of the defeathering process was observed to be higher than the other wastewater sources (Table 1).

\subsection{Estimated Cost}

Despite the initial cost of the Gr electrode being relatively higher compared to Fe and Al electrodes, it was observed to form the best combination due to its stability and reusability [59]. The total operating cost for Fe-Fe ranged from $1.55 \mathrm{US} \$ / \mathrm{m}^{3}$ to $3.51 \mathrm{US} \$ / \mathrm{m}^{3}$ of purified water, while that of Fe-Gr ranged from $0.83 \mathrm{US} \$ / \mathrm{m}^{3}$ to $1.93 \mathrm{US} \$ / \mathrm{m}^{3}$ of purified water after $10 \mathrm{~min}$ of the treatment process. After multiple experiments, the Al-Gr electrode combination was found to be the most efficient not only in the treatment performance but also in the cost of operation. Al-Gr achieved high purification efficiency after $40 \mathrm{~min}$ of the treatment process. The average cost after $40 \mathrm{~min}$ for Al-Gr combination was estimated to be $2.3 \mathrm{US} \$ / \mathrm{m}^{3}, 2.0 \mathrm{US} \$ / \mathrm{m}^{3}$, and $1.3 \mathrm{US} \$ / \mathrm{m}^{3}$ of purified water for defeathering, evisceration, and cooling samples, respectively (Figure 6). In general, the wastewater from the defeathering section was associated with the highest operating cost from both time and electrode combination factors. The phenomenon, which may be linked to the relatively high pollution strength of defeathering wastewater compared to the evisceration and cooling sections.

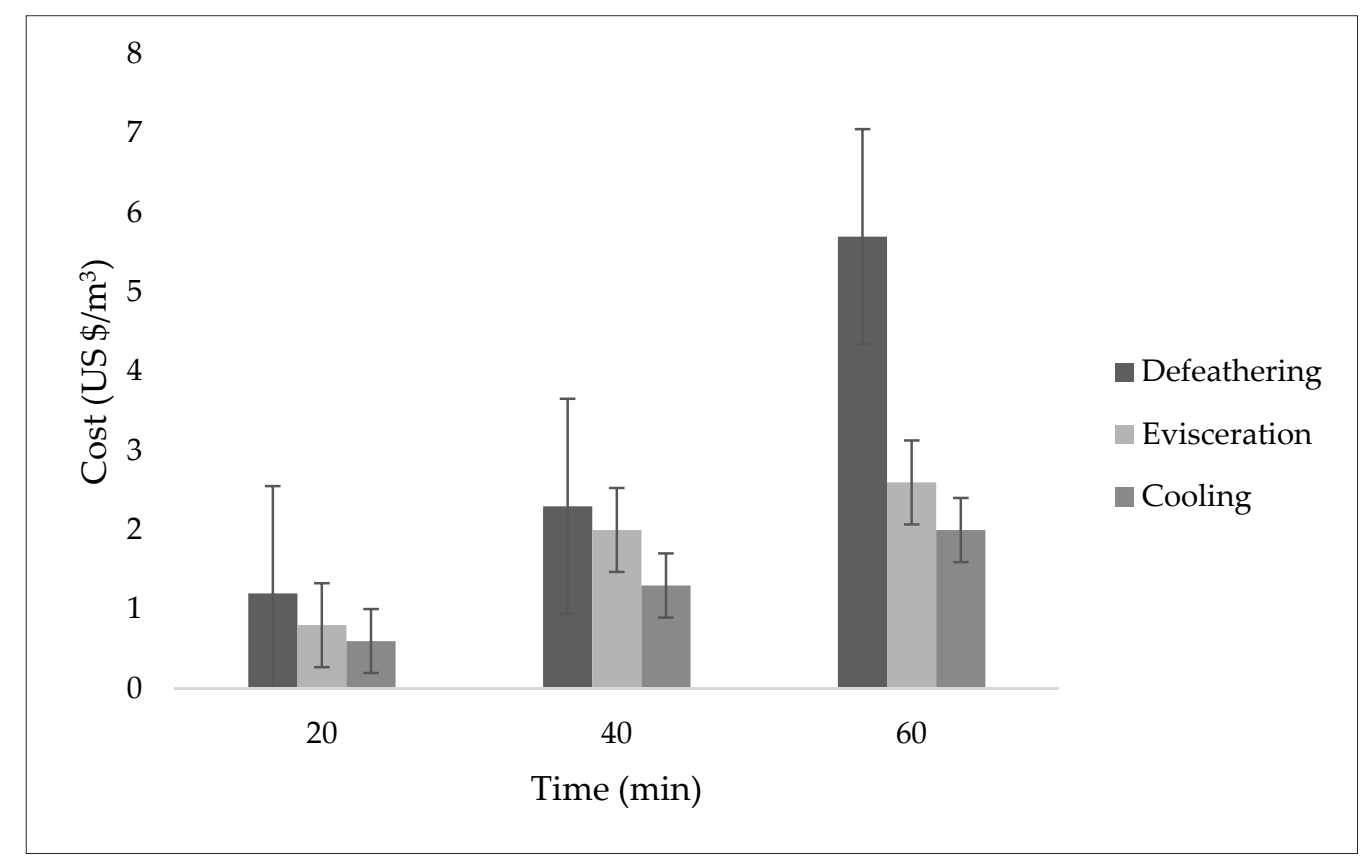

Figure 6. Operating cost over time (Al-Gr). 


\section{Conclusions}

The potential influence of electrode combination on the treatability of a poultry slaughterhouse wastewater was studied. In this study, the efficiency of three different electrode combinations (Fe-Fe, Fe-Gr, and Al-Gr) for electrochemical treatment technology was evaluated with drinking water quality standards as references. The samples were analyzed before and after the purification to determine the treatment efficiency of the investigated combinations of electrodes. Water quality classification for the samples treated using Fe-Fe, Fe-Gr, and Al-Gr was successfully achieved using WQIs. From this study, the Al-Gr electrode combination showed an impressive treatment performance, achieving an "excellent" status for all of the three studied sources of wastewater. From the developed WQIs, this study was able to reveal that the wastewater from the evisceration process in the poultry slaughterhouse had higher quality after the purification process compared to that of defeathering and cooling processes. To improve the performance of $\mathrm{Fe}-\mathrm{Fe}$ electrodes and the defeathering process combination, it would be ideal to integrate the combination with a post-treatment unit, especially for the removal of turbidity and COD. In general, seven out of nine WQIs developed in this study indicated an impressive performance of the electrochemical electrodes studied. In general, the use of WQI provides a relatively easy-to-understand approach for presenting information related to water quality to experts and non-experts. The findings of this study show how a change in electrode combination may influence the treatment performance of an electrochemical plant. The results reveal further the possibility of unexpected behavior when applying a certain type of electrode combination. From the developed WQIs, it is also evident that depending on the sources of wastewater, the treatment efficiency of a wastewater treatment system may be affected. Moreover, the Al-Gr electrode combination was also found to be the most cost-effective option among the studied electrode combinations.

Author Contributions: Conceptualization and methodology, K.M.; software, D.O.; validation, T.M., D.O., and E.T.; formal analysis, Z.J. and A.K.; investigation, resources, and data curation, V.J.I.; writing-K.M. and T.M.; visualization and supervision, V.J.I.; project administration, K.M.; funding acquisition, K.M. All authors have read and agreed to the published version of the manuscript.

Funding: This research was funded by the Ministry of Education and Science, the Republic of Kazakhstan to support "Reducing the technogenic impact on water resources with using water recycling technology", № BR05236844/215 for 2018-2020.

Conflicts of Interest: The authors declare no conflict of interest. The funders had no role in the design of the study; in the collection, analyses, or interpretation of data; in the writing of the manuscript, or in the decision to publish the results.

\section{References}

1. Kazemi-Bonchenari, M.; Alizadeh, A.; Javadi, L.; Zohrevand, M.; Odongo, N.E.; Salem, A.Z.M. Use of poultry pre-cooked slaughterhouse waste as ruminant feed to prevent environmental pollution. J. Clean. Prod. 2017, 145, 151-156. [CrossRef]

2. Rajakumar, R.; Meenambal, T.; Banu, J.R.; Yeom, I.T. Treatment of poultry slaughterhouse wastewater in upflow anaerobic filter under low upflow velocity. Int. J. Environ. Sci. Technol. 2011, 8, 149-158. [CrossRef]

3. Amorim, A.K.B.; de Nardi, I.R.; Del Nery, V. Water conservation and effluent minimization: Case study of a poultry slaughterhouse. Resour. Conserv. Recycl. 2007, 1, 93-100. [CrossRef]

4. Yordanov, D. Preliminary study of the efficiency of ultrafiltration treatment of poultry slaughterhouse wastewater. Bulg. J. Agric. Sci. 2010, 16, 700-704.

5. Bazrafshan, E.; Kord Mostafapour, F.; Farzadkia, M.; Ownagh, K.A.; Mahvi, A.H. Slaughterhouse wastewater treatment by combined chemical coagulation and electrocoagulation process. PLoS ONE 2012, 7. [CrossRef]

6. Mickova, I. Advanced Electrochemical Technologies in Wastewater Treatment Part I: Electrocoagulation. Am. Sci. Res. J. Eng. Technol. Sci. 2015, 14, 233-257.

7. Muddemann, T.; Haupt, D.; Sievers, M.; Kunz, U. Electrochemical Reactors for Wastewater Treatment. ChemBioEng Rev. 2019, 6, 142-156. [CrossRef] 
8. Radjenovic, J.; Sedlak, D.L. Challenges and Opportunities for Electrochemical Processes as Next-Generation Technologies for the Treatment of Contaminated Water. Environ. Sci. Technol. 2015, 49, 11292-11302. [CrossRef]

9. Meiramkulova, K.; Userbayev, M.; Aubakirova, K.; Saiyabayev, K.; Suleimenova, B. Electrochemical treatment of poultry industry wastewater. Int. J. Mech. Eng. Technol. 2018, 9, 1285-1293.

10. Garcia-Segura, S.; Ocon, J.D.; Chong, M.N. Electrochemical oxidation remediation of real wastewater effluents-A review. Process Saf. Environ. Prot. 2018, 113, 48-67. [CrossRef]

11. Meiramkulova, K.; Zhumagulov, M.; Saspugayeva, G.; Jakupova, Z.; Mussimkhan, M. Treatment of poultry slaughterhouse wastewater with combined system. Potravin. Slovak J. Food Sci. 2019, 1, 2019. [CrossRef]

12. Bayramoglu, M.; Kobya, M.; Eyvaz, M.; Senturk, E. Technical and economic analysis of electrocoagulation for the treatment of poultry slaughterhouse wastewater. Sep. Purif. Technol. 2006, 51, 404-408. [CrossRef]

13. Bazrafshan, E.; Moein, H.; Kord Mostafapour, F.; Nakhaie, S. Application of electrocoagulation process for dairy wastewater treatment. J. Chem. 2013. [CrossRef]

14. Cerqueira, A.; Russo, C.; Marques, M.R.C. Electroflocculation for textile wastewater treatment. Braz. J. Chem. Eng. 2009, 26, 659-668. [CrossRef]

15. Daneshvar, N.; Khataee, A.R.; Amani Ghadim, A.R.; Rasoulifard, M.H. Decolorization of C.I. Acid Yellow 23 solution by electrocoagulation process: Investigation of operational parameters and evaluation of specific electrical energy consumption (SEEC). J. Hazard. Mater. 2007, 148, 566-572. [CrossRef]

16. Gomes, A.J.G.; Atambo, D.O.; Das, K.K.; Cocke, D.L.; Das, K.P. Electrochemical remediation of chicken processing plant wastewater. J. Environ. Chem. Eng. 2018, 6, 6028-6036. [CrossRef]

17. Thirugnanasambandham, K.; Kandasamy, S.; Sivakumar, V.; Kumar, R.K.; Mohanavelu, R. Modeling of by-product recovery and performance evaluation of Electro-Fenton treatment technique to treat poultry wastewater. J. Taiwan Inst. Chem. Eng. 2015, 46, 89-97. [CrossRef]

18. Eryuruk, K.; Tezcan Un, U.; Bakır Ogutveren, U. Electrochemical treatment of wastewaters from poultry slaughtering and processing by using iron electrodes. J. Clean. Prod. 2018, 172, 1089-1095. [CrossRef]

19. Yousefi, Z.; Sahebian, H.; Amouei, A.; Mohammadpour, R.A.; Zarei, E. Process performance with DC current in treatment of poultry slaughterhouse wastewater using aluminum electrodes. J. Maz. Univ. Med. Sci. 2019, $29,53-66$.

20. Mendoza Combatt, M.P.; Mendonça, R.C.S.; Valente, G.S.; Silva, C.M. Validação do processo de eletrocoagulação e avaliação da eletrodissolução de eletrodos no tratamento de efluentes de abatedouros de aves. Quim. Nova 2017, 40, 447. [CrossRef]

21. Zhou, M.; Chi, M.; Luo, J.; He, H.; Jin, T. An overview of electrode materials in microbial fuel cells. J. Power Sources 2011, 196, 4427-4435. [CrossRef]

22. He, W.; Wallack, M.J.; Kim, K.-Y.; Zhang, X.; Yang, W.; Zhu, X.; Feng, Y.; Logan, B.E. The effect of flow modes and electrode combinations on the performance of a multiple module microbial fuel cell installed at wastewater treatment plant. Water Res. 2016, 105, 351-360. [CrossRef] [PubMed]

23. Godini, K.; Azarian, G.; Nematollahi, D.; Rahmani, A.R.; Zolghadrnasab, H. Electrochemical treatment of poultry slaughterhouse wastewater using iron and aluminium electrodes. Res. J. Chem. Environ. 2012, 16, 98-103.

24. Paulista, L.O.; Presumido, P.H.; Theodoro, J.D.P.; Pinheiro, A.L.N. Efficiency analysis of the electrocoagulation and electroflotation treatment of poultry slaughterhouse wastewater using aluminum and graphite anodes. Environ. Sci. Pollut. Res. 2018, 25, 19790-19800. [CrossRef] [PubMed]

25. Asselin, M.; Drogui, P.; Benmoussa, H.; Blais, J.F. Effectiveness of electrocoagulation process in removing organic compounds from slaughterhouse wastewater using monopolar and bipolar electrolytic cells. Chemosphere 2008, 72, 1727-1733. [CrossRef] [PubMed]

26. Nikoo, M.R.; Kerachian, R.; Malakpour-Estalaki, S.; Bashi-Azghadi, S.N.; Azimi-Ghadikolaee, M.M. A probabilistic water quality index for river water quality assessment: A case study. Environ. Monit. Assess. 2011, 181, 465-478. [CrossRef] [PubMed]

27. Tyagi, S.; Sharma, B.; Singh, P.; Dobhal, R. Water quality assessment in terms of Water Quality Index. Int. Res. J. Eng. Technol. 2017. Available online: https://www.researchgate.net/publication/259495159_Water_Quality_ Assessment_in_Terms_of_Water_Quality_Index (accessed on 28 March 2020).

28. Liou, S.M.; Lo, S.L.; Wang, S.H. A generalized water quality index for Taiwan. Environ. Monit. Assess. 2004, 96, 35-52. [CrossRef] 
29. Dos Simões, F.S.; Moreira, A.B.; Bisinoti, M.C.; Gimenez, S.M.N.; Yabe, M.J.S. Water quality index as a simple indicator of aquaculture effects on aquatic bodies. Ecol. Indic. 2008, 8, 476-484. [CrossRef]

30. Boyacioglu, H. Development of a water quality index based on a European classification scheme. Water $S A$ 2009, 33. [CrossRef]

31. Yidana, S.M.; Yidana, A. Assessing water quality using water quality index and multivariate analysis. Environ. Earth Sci. 2010, 59, 1461-1473. [CrossRef]

32. Boyacioglu, H. Utilization of the water quality index method as a classification tool. Environ. Monit. Assess. 2010, 167, 115-124. [CrossRef] [PubMed]

33. Kachroud, M.; Trolard, F.; Kefi, M.; Jebari, S.; Bourrié, G. Water Quality Indices: Challenges and Application Limits in the Literature. Water 2019, 11,361. [CrossRef]

34. De Rosemond, S.; Duro, D.C.; Dubé, M. Comparative analysis of regional water quality in Canada using the Water Quality Index. Environ. Monit. Assess. 2009, 156, 223-240. [CrossRef] [PubMed]

35. Srebotnjak, T.; Carr, G.; De Sherbinin, A.; Rickwood, C. A global Water Quality Index and hot-deck imputation of missing data. Ecol. Indic. 2012, 17, 108-119. [CrossRef]

36. Karbassi, R.A.; Mir Mohammad Hosseini, F.; Baghvand, A.; Nazariha, M. Development of water quality index (WQI) for gorganrood river. Int. J. Environ. Res. 2011, 5, 1041-1046. [CrossRef]

37. Koçer, M.A.T.; Sevgili, H. Parameters selection for water quality index in the assessment of the environmental impacts of land-based trout farms. Ecol. Indic. 2014, 36, 672-681. [CrossRef]

38. Palmer, M. Standard Operating Procedure for GLNPO Total Alkalinity Titration; United States Environmental Protection Agency. Great Lakes National Program Office: Washington, DC, USA, 1992; pp. 5-10.

39. Mulvany, J.G. Chapter VII Membrane Filter Techniques in Microbiology. In Methods in Microbiology; Elsevier: Amsterdam, The Netherlands, 1998; Volume 1, pp. 205-253. ISBN 0-87553-235-7.

40. American Public Health Association (APHA). Standard Methods for the Examination of Water $\mathcal{E}$ Wastewater, 21st ed.; American Public Health Association (APHA): Washington, DC, USA, 1999.

41. Ichwana, I.; Syahrul, S.; Nelly, W. Water Quality Index by Using National Sanitation Foundation-Water Quality Index (NSF-WQI) Method at Krueng Tamiang Aceh. In Proceedings of the First International Conference on Technology, Innovation and Society, Padang, Indonesia, 21-22 July 2016; ITP Press: Dubai, UAE, 2016; pp. 110-117. [CrossRef]

42. Mehra, A.; Bhatia, P.R.K.; Verma, P.S. Assessment of Water Quality Index of Different Sources of Water Supply in Jabalpur. Int. J. Innov. Res. Sci. Eng. Technol. 2017, 19905-19911.

43. Batabyal, A.K.; Chakraborty, S. Hydrogeochemistry and Water Quality Index in the Assessment of Groundwater Quality for Drinking Uses. Water Environ. Res. 2015, 87, 607-617. [CrossRef]

44. Mihu-Pintilie, A.; Paiu, M.; Breabăn, I.G.; Romanescu, G. Status of water quality in cuejdi hydrographic basin from eastern Carpathian, Romania. In Proceedings of the International Multidisciplinary Scientific GeoConference Surveying Geology and Mining Ecology Management, SGEM, Albena, Bulgaria, 17-26 June 2014.

45. Sahu, O.; Mazumdar, B.; Chaudhari, P.K. Treatment of wastewater by electrocoagulation: A review. Environ. Sci. Pollut. Res. 2014, 21, 2397-2413. [CrossRef]

46. Vidal, J.; Espinoza, C.; Contreras, N.; Salazar, R. Elimination of industrial textile dye by electrocoagulation using iron electrodes. J. Chil. Chem. Soc. 2017, 62, 3519-3524. [CrossRef]

47. Malakootian, M.; Yousefi, N.; Fatehizadeh, A. Survey efficiency of electrocoagulation on nitrate removal from aqueous solution. Int. J. Environ. Sci. Technol. 2011, 8, 107-114. [CrossRef]

48. Moussa, D.T.; El-Naas, M.H.; Nasser, M.; Al-Marri, M.J. A comprehensive review of electrocoagulation for water treatment: Potentials and challenges. J. Environ. Manag. 2017, 186, 24-41. [CrossRef] [PubMed]

49. Schmalz, V.; Dittmar, T.; Haaken, D.; Worch, E. Electrochemical disinfection of biologically treated wastewater from small treatment systems by using boron-doped diamond (BDD) electrodes - Contribution for direct reuse of domestic wastewater. Water Res. 2009, 43, 5260-5266. [CrossRef] [PubMed]

50. Amfo-Otu, R.; Agyenim, J.B.; Nimba-Bumah, G.B. Correlation Analysis of Groundwater Colouration from Mountainous Areas, Ghana. Environ. Res. Eng. Manag. 2014, 67. [CrossRef]

51. Nasrabadi, T.; Ruegner, H.; Sirdari, Z.Z.; Schwientek, M.; Grathwohl, P. Using total suspended solids (TSS) and turbidity as proxies for evaluation of metal transport in river water. Appl. Geochem. 2016, 68, 1-9. [CrossRef] 
52. Sadar, M.J. Turbidity Science. Tech. Inf. Ser. 2003. Available online: https://www.hach.com/asset-get. download-en.jsa?code=61792 (accessed on 14 March 2020).

53. Li, J.; Luo, G.; He, L.; Xu, J.; Lyu, J. Analytical Approaches for Determining Chemical Oxygen Demand in Water Bodies: A Review. Crit. Rev. Anal. Chem. 2018, 48, 47-65. [CrossRef]

54. Huang, X.; Qu, Y.; Cid, C.A.; Finke, C.; Hoffmann, M.R.; Lim, K.; Jiang, S.C. Electrochemical disinfection of toilet wastewater using wastewater electrolysis cell. Water Res. 2016, 92, 164-172. [CrossRef]

55. Drees, K.P.; Abbaszadegan, M.; Maier, R.M. Comparative electrochemical inactivation of bacteria and bacteriophage. Water Res. 2003, 37, 2291-2300. [CrossRef]

56. Aguiar, M.M.; Ferreira, L.F.R.; Monteiro, R.T.R. Use of vinasse and sugarcane bagasse for the production of enzymes by lignocellulolytic fungi. Brazilian Arch. Biol. Technol. 2010, 53, 1245-1254. [CrossRef]

57. Baker, B. Explore the Pollution Load of Slaughterhouse Wastewater and Their Treatment Potential Using Biofilm Reactor. Int. J. Sci. Eng. Res. 2016, 7, 1757-1761.

58. Rashid, S.S.; Liu, Y.Q. Assessing environmental impacts of large centralized wastewater treatment plants with combined or separate sewer systems in dry/wet seasons by using LCA. Environ. Sci. Pollut. Res. 2020, 27, 15674-15690. [CrossRef] [PubMed]

59. Xiong, S.; Li, X.; Zhao, C.; Gao, J.; Yuan, W.; Zhang, J. The Degradation of Deoxynivalenol by Using Electrochemical Oxidation with Graphite Electrodes and the Toxicity Assessment of Degradation Products. Toxins (Basel) 2019, 11, 478. [CrossRef]

(C) 2020 by the authors. Licensee MDPI, Basel, Switzerland. This article is an open access article distributed under the terms and conditions of the Creative Commons Attribution (CC BY) license (http://creativecommons.org/licenses/by/4.0/). 